\title{
Bendi : Transportasi Budaya di Kota Solok Sumatera Barat Antara Tantangan dan Peluang Tahun 1970-2000
}

\author{
Mila Yefriza*, I Ketut Ardhana, Anak Agung Ayu Rai Wahyuni \\ Prodi Sejarah, Fakultas Ilmu Budaya, Universitas Udayana \\ [milayefriza3@gmail.com] \\ Denpasar Bali Indonesia \\ *Corresponding Author
}

\begin{abstract}
This study has discussed about the existence of traditional transportation in the Solok city in 1970 or it's called bendi transportation. Bendi is a traditional transportation which still existed until 2000 in the middle of more sophisticated transportation in that era. This study has three problems to be discussed, they are (1) Why the bendi transportation still existed in the Solok, West Sumatra? (2) What are the challenges of bendi tansportation as traditional transportation in the Solok, West Sumatra? (3) What are the role of government in it?. This study used city's historical method and theory of history and social science by Wellman and Wortley in a modern sociology by George Ritzer were applied. The results of this study reveals thatbendi isa traditional transportation which still existed in the Solok, it's describes the challenges of bendi as traditional transportation, and explains how the government plays a role in maintaining and preserving bendi as a traditional transportation asset in Solok, West Sumatra.
\end{abstract}

Keywords: Transportation, Bendi, Road, Carman.

\begin{abstract}
Abstrak
Penelitian ini membahas tentang keberadaan transportasi budaya di Kota Solok tahun 1970 yang disebut dengan bendi sebuah alat transportasi tradisional yang masihbertahanhinggatahun 2000 ditengah-tengah berkembangnya transportasi modern yang lebih cangih darinya. Adapun permasalahan yang akan dibahas dalam penelitian ini adalah (1) Mengapa transportasi bendi masih bertahan di Kota Solok Sumatera Barat (2) Apa tantangan yang dihadapi transportasi bendi sebagai transportasi budaya di Kota Solok Sumatera Barat (3) Bagaimana peran pemerintah terhadap keberadaan transportasi bendi yang masih ada di Kota Solok. Dalam penelitian ini menggunakan metodologi sejarah kota. Teori yang digunakan dalam penelitian ini merupakan teori sejarah dan teori ilmu sosial teori jaringan dari Wellman dan Wortley dalam buku teori sosiologi modern yang ditulis oleh George Ritzer.Hasil penelitian ini mengungkapkan bahwa kebaradaan transportasi bendi merupakan transportasi budaya yang masihada di Kota Solok, mengambarkan tantangan yang dihadapi oleh transportasi tradisonal bendi sebagai transportasi budaya, dan menjelaskan bagaimana peran pemerintah dalam mempertahankan dan melestarikan bendi sebagai aset transportasi budaya di Kota Solok.
\end{abstract}

Kata Kunci:Transportasi, Bendi, Jalan, kusir. 


\section{PENDAHULUAN}

Kota Solok terletak dijalur lintas Sumatera merupakan daerah yang dilalui dan disinggahi oleh setiap orang yang melakukan perjalanan. Kota Solok telah menjadi kota persingahan yang sangat banyak dilalui pedagang yang akan melakukan perlintasan dari Sumatera bagian Utara antara Sumatera bagian Selatan atau sebaliknya. Kota Solok juga berada pada persimpangan jalur transportasi darat pulau Sumatera yang menghubungkan kawasan Sumatera bagian Barat dengan kawasan Sumatera Bagian Timur (Berita Daerah Kota Solok, 2014:11).

Pada tahun 1970 Solok diresmikan menjadi Kotamadya, berdasarkan Peraturan Menteri Dalam Negeri Nomor 8 tahun tahun 1970 tanggal 16 Desember 1970 ditetapkan kota Solok sebagai daerah Otonom Pemerintah Tingkat II Kotamadya Solok. Untuk memenuhi kehidupan manusia kota Solok membutuhkan sarana prasarana transportasi dibandingkan pedesaan, selain kuli dan kuda sarana transportasi yang populer adalah pedati dan bendi. (Gusti Asnan, 2002: 727). Transportasi umum yang digunakan oleh mayarakat kota Solok adalah bendi yang merupakan sebuah transportasi kareta beroda dua yang di tarik oleh seekor kuda.

Sebelum kota Solok menjadi Kotamadya pada tahun 1970, bendi merupakan kendaraan pribadi penghulu dan bangsawan, atau di sewakan kepada pedagang kaya sebagai semacam simbol pratise atau status sosial bagi mereka. Pada tahun 1970 bendi mengalami sedikit pergeseran dari kendaraan penghulu atau pribadi menjadi kendaraan umum, yang dapat dimiliki oleh siapa saja lapisan masyarakat kota Solok. (Fikrul Hanif, dkk, 2017:53). Pada saat itulah bendi sudah banyak terlihat di jalan-jalan raya yang mengangkut para penumpang untuk sampai pada tujuan mereka.
Pada tahun 1980 kendaraan lainya seperti bemo mulai masuk ke kota solok, namun keberadaan bendi tidak tersingkirkan dengan adanya angkutan lain di kota Solok, kendaraan tersebut tetap berjalan sebagaimana mestinya, karena transportasi merupakan kebutuhan dalam system kehidupan, pemerintah, masyarakat dan sosial (Siti Aminah, 2018: 1142). Transportasi bendi dijadikan sebagai transportasi budaya bagi masyarakat kota Solok yang tidak menginginkan kepunahanya.

Ditengah perkembangan transportasi lain, bendi masih menjadi salah satu moda transportasi utama yang belum kalah bersaing dengan bemo, mobil, dan opelet. Orang-orang masih mengunaan bendi sebagai alat transportasi populer, sekalipun tidak lagi untuk perjalananperjalanan jarak jauh, bendi digunakan untuk sarana angkutan jarak dekat antara antara pasar ke pasar dan sebagai angkutan dalam kota saja.

Untuk tulisan sejarah transportasi bendi dalam kajian sastrawan, budayawan, filsafat, jurnalisme dan bidang ilmu keguruan sudah ada yang menulis, tapi sangat sedikit yang membahas tentang tantangan dan peran pemerintah dalam mempertahankanya, dari fenomena tersebut tertarik hati penulis untuk membahas bendi sebagai transportasi budaya di Kota Solok dengan menggunakan kajian historis melalui penelitian ini.

Tidak cukup dengan alasan tersebutbanyak masyarakat kini justru kurang paham secara benar konteks transportasi budaya. Tetapi meskipun demikian penelitian ini akan berusaha seobjektif mungkin berbicara mengenai keberadaan, tantangan dan peran pemerintah dalam melestarikanya.

Berdasarkan uraian di atas, muncul permasalahan yang akan dibahas dalam penelitian ini (1) Mengapa transportasi bendi masih bertahan di Kota Solok 
Sumatera Barat (2) Apa tantangan yang dihadapi transportasi bendi sebagai transportasi budaya di Kota Solok Sumatera Barat (3) Bagaimana peran pemerintah terhadap keberadaan transportasi bendi yang masih ada di Kota Solok.

Adapun tujuan penelitian ini adalah sebagai berikut (1)Untuk mengetahui bahwa transportasi bendi masih bertahan dan diminati oleh masyarakat Minang khusunya kota Solok, (2) Untuk mengetahui informasi sebanyakbanyaknya terkait bendi sebagai transportasi budaya di Kota Solok Sumatera Barat, (3) Untuk mengetahui tantangan apa saja yang di hadapi oleh transportasi bendi sebagai transportasi budaya di kota Solok Sumatera Barat, (4) Untuk mengetahui peran pemerintah terhadap keberadaan transporatsi bendi sebagai transportasi budaya di kota Solok Sumatera Barat.

\section{METODE}

Metode yang digunakan dalam penelitian ini adalah metode sejarah. proses menganalisa rekaman dan peninggalan masa lampau. Berdasarkan data yang diperoleh dalam menjalani proses itu disebut dengan historiografi atau penulisan sejarah Metode sejarah dapat dibagi atas empat kelompok kegiatan. (1) Heuristik (2) Kritik atau verifikasi, (3) Interpretasi, dan (4) Historiografi.

Dalam pengumpulan sumber-sumber penelitian, penulis mengunakan data-data berupa wawancara, dokuman, arsip dan gambar, serta sumber pustaka yang berkaitan dengan penelitian ini.

\section{HASIL DAN PEMBAHASAN}

\section{Keberadaan Transportasi Bendi di Kota Solok Sumatera Barat Tahun 1970-2000.}

Kota Solok merupakan daerah yang penting di daerah tingkat I Sumatera
Barat. Arti penting dari kota ini adalah dari segi lalu lintas, karena kota ini terletak di persimpangan jalan dan merupakan pintu gerbang bagi lalu lintas yang berasal dari daerah selatan. Letak kota Solok sangat strategis dan perhubungan yang semakin lancar, menempatkan kota ini sebagai kota perdagangan, pendidikan dan sebagai pusat pengembangan. Disamping itu kota Solok adalah daerah agraris yang menjadi pusat mata pencaharian masyarakat sebagai petani yaitu lahan basah seperti sawah. Bekerja sebagai petani saja tidaklah cukup untuk memenuhi kehidupan sehari-hari, dan mengaharuskan tambahan pekerjaan yang lain seperti perdagangan, industri, dan kusir bendi, yaitu sebuah alat transportasi tradisional yang masih berfungsi di kota Solok, menjadi kusir bendi pada tahun 1970 adalah pekerjaan yang sangat menguntungkan dan merupakan mata pencaharian bagi masyarakat kota Solok (Nelma Sari dkk, 2018: 403), karena transportasi ini sudah dijadikan sebagai transportasi umum pada saat Solok menjadi Kotamadya.

Atas kebijakan pemerintah kota Solok akhirnya dikeluarkan surat keputusan walikotamadya kepala TK II Solok No.188.45/02/SK/WSL-1988 tanggal 08-01-1988, yaitu tentang jalur pangkalan bendi dan opelet, sejak saat itu bendi dan opelet mempunyai jalaur tersendiri. Transportasi bendi mempunyai jalur yang berbeda pertama jalur kearah Simpang Rumbio, kedua jalur kearah Salayo dan Tanah Garam, yang ketiga jalur kerah Pandan, Tanjung Paku, serta Nan Balimo. Dari arah yang sudah di tentukan tersebut, banyak masyarakat kota Solok mengunakan transportasi bendi untuk berpergian seperti ke pasar, sekolah kantor dan lain sebagainya. Hal ini menunjukan trasnportasi bendi masih banyak digunakan oleh masyarakat hingga tahun 2000. Keberadaanya di kota Solok di pengaruhi oleh tiga fakto yaitu 
pertama faktor ekonomi, kebutuhan ekonomi yang semakin hari semakin banyak, menuntut para kusir bendi untuk tetap menjadikan bendi sebagai salah satu sumber mata pencarian mereka. (Riri Dwivivindra, dkk, 2015: 72)

Walaupun transportasi ini tidak sebanyak pada tahun 90-an akan tetapi masih ada beberapa puluhan bendi yang dioperasikan di kota Solok, kurang lebih 15-20 bendi yang masih ada di kota Solok. (Eko Juandri, dkk, 2018: 812). Kedua faktor pariwisata Keberadaan transportasi bendi sebagai pariwisata di kota Solok merupakan sebuah industri ekonomi yang dapat mendukung ekonomi masyarakat kota Solok (Andrean Maulana, 2018: 193). Ketiga faktor budaya transportasi bendi dianggap sebagai benda budaya peningalan sejarah Minangkabau. Transportasi bendi dapat dikatakan sebuah benda budaya, yang diwarisis secara turun temurun oleh masyarakat Minangkabau (Limbak Tjahaja, 1955: 24). Transportasi bendi digunakan untuk upacara perkawinan, khatam al-quran, acara kenagarian dan bahkan arak-arakan wisudawan (Lisa Wahyuni, 2017: 187).

\section{Tantangan Yang Dihadapi Transportasi Bendi di Kota Solok Sumatera Barat Tahun 1970-2000}

Tantangan merupakan sebuah hambatan dalam melakukan usaha, baik itu usaha yang dilakukan sendiri maupun usaha yang dilakukan secara bersamasama. Pada tahun 1970 bendi bukan hanya sebagai sarana transportasi untuk mengangkut para penumpanng saja, akan tetapi juga dijadikan sebagai sarana untuk mengangkut hasil pertanian masyarakat kota Solok yaitu beras. Memasuki tahun 2000 zaman menjadi tidak berpihak lagi kepada trasnportasi bendi Seiring pertumbuhan kota-kota modern dan semakin pesatnya perusahaan otobus, sehingga kuda-bendi terdepak lebih jauh lagi. Keudikannya yang kontradiktif dengan pembangunan yang tengah hingar-bingar dicanangkan. Trayek untuk bendi semakin dipersempit bahkan sudah mulai terlihat dari tahun 1990.

Setiap benda budaya yang ada di suatu daerah baik yang bergerak maupun yang tidak bergerak, tentu masyarakat ingin melestarikan keberadaanya. Untuk mewujudkan situasi yang demikian setiap upaya dalam melestarikan keberadaan benda budaya terutama transportasi bendi akan menghadapi tantangan-tantangan. Adapun tantangan yang dihadapi transportasi bendi di kota Solok Sumatera Berat adalah sebagai berikut pertama munculnya transportasi laian yang tidak dapat dielakan lagi. Kehadiran transportasi lain seperti motor, mobil, bemo, angkot dan lain sebagainya di kota Solok, menjadikan kota Solok semakin berkembang untuk membangun perekonomian dan pertumbuhan industrialisasi (Sakti Adjie Adisasmita, 2012: 8). Banyaknya transportasi yang beroperasi dikota Solok menimbulkan persaingan diantara para supir kendaraan, belum lagi angkot yang manwarkan tarif yang murah dibandingan bendi, sehingga masyarakat memiliki banyak pilihan untuk menaiki transportasi. Ditambah lagi pada tahun 2000 rata-rata masyarakat sudah banyak mengunakan kendaraan pribadi, sehingga bendi menjadi terpingirkan akan tetapi tidak hilang begitu saja, keberadaannya di kota Solok lebih kurang 40 an bendi yang masih beroperasi.

Kedua keterbatasan sumber daya manusia, untuk mengemudi transportasi jenis apapun sangat di perlukan (Muh. Kadarisman, dkk, 2016: 3). Mengemudi bendi atau menjadi kusir sudah hampir tidak ada lagi, sumber daya manusia untuk bekerja sebagai kusir bendi mulai menurun, disebabkan oleh tidak adanya ketertarikan masyarakat atau generasi muda untuk bekerja sebagai kusir bendi walaupun untuk meneruskan usaha orang 
tuanya. Berbeda dengan tahun 1970 sampai tahun 1990 para kusir bendi mengajarkan secara turun temurun bagaimana mengendarai bendi dan merawatnya kepada keluarganya seperti anak-anaknya maupun cucu-cucu mereka, karena pada saat itu bekerja sebagai kusir bendi dapat mencukupi kehidupan sehari-hari.

Ketiga ketiadaan terminal bendi, sejak dulunya memang tidak ada terminal khusus untuk transportasi bendi, akan tetapi ada lahan parkir untuk bendi sesuai tujuan atau jurusun bendi hendak kemana. Oleh sebeb itulah terminal bendi atau tempat pemberhentian bendi perlu ada di kota Solok untuk menjaga agar transportasi bendi tetap ada dan tetap berfungsi, jika diberikan ruang gerak untuk transportasi ini beroperasi.

\section{Peran Pemerintah Dalam Mempertahankan Keberadaan Bendi di Kota Solok}

Kendaraan bendi yang beroperasi dikota solok sebagai tranportasi budaya yang digerakan oleh hewan juga mendapat perhatian dari pihak pemerintah untuk tetap menjaga dan melestarikan benda budaya tersebut. Adapun langkah-langkah pemerintah dalam melestarikan transportasi bendi adalah sebagai berikut. Pertama melakukan pengujian terhadap transportasi bendi Pemerintah kota Solok melakukan uji KIR kepada setiap kendaraan yang beroperasi di kota Solok yang merupakan serangkaian kegiatan menguji dan memeriksa bagian-bagian kendaraan transportasi baik kendaraan bermotor, kereta gendengan, kereta tempelan, kendaraan khusus maupun bendi, dalam rangka pemenuhan terhadap persyaratan teknis dan baik dalam mengunakan lalu lintas (Elsa Tri Mukti, 2014: 206). Pengujian tersebut meliputi uji tipe dan uji berkala Hal ini dilakukan pemerintah sebagai upaya melestarikan bendi sebagai transportasi budaya yang tetap eksis di kota Solok.

Kedua memberi izin mengemudi serta izin treyek untuk transportasi bendi yang beroperasi di kota Solok. Dasar hukum yang mengatur kepemilikan surat izin mengemudi (SIM) adalah UndangUndang No. 14 Tahun 1992. Dalam Undang-Undang ini dijelaskan bahwa tiap pengemudi kendaraan bermotor, baik roda dua maupun lebih diwajibkan memiliki dan membawa SIM ketika mengendarai kendaran. Serta PP No. 44 Tahun 1993 tentang kendaraan dan pengemudi, bahwa setiap kendaraan wajib memiliki surat izin mengemudi (Henry S. Siswosoediro, 2009: 39-40) hal ini juga berlaku kepada trasnportasi bendi yang akan beroperasi dikota Solok, namun sejak tahun 2000 SIM tidak lagi dimiliki oleh kusir bendi disebabkan sedikitnya trasnportasi bendi yang beroperasi di kota Solok.

Ketiga adalah pemerintah merencanakan trasnportasi berkelanjutan di kota Solok penguna bahan bakan tikat keamanan dan kemacetan tidak menimbulkan dampak negatif (Nicolas, Brotodewo, 2010: 166) serta mengunakan sumber energi terbarukan, dapat mendaur ulang komponen kendaraan, dan dapat meminilisir pengunaan lahan (Mahditia Paramita, 2016: 72) Transportasi bendi merupakan tranportasi yang ramah lingkungan dan tidak menebarkan polusi udara, sehingga dapat mewujudkan system transportasi berkelanjutan, dan mengurangi kemacetan (Sugeng Wiyono, 2012: 2) Hanya saja transportasi ini tidak dapat bergerak cepat karena mengunakan tenaga hewan, walupun demikian bendi juga memiliki kelebihan dan kelemahan sebagai sarana angkutan umum yang akan digunakan oleh masyarakat.

\section{SIMPULAN}

Bendi merupakan alat transportasi yang ditarik oleh kuda atau mengunakan 
tenaga hewan merupakan transportasi umum masyarakat kota Solok saat Solok diresmikan menjadi Kotamasya pada tahun 1970. Transportasi bendi menjadi populer pada saat itu hingga tahun 1990 bendi menjadi angkutan umum masyarakat kota Solok yang hendak berpegian baik jarak dekat maupun jarak jauh, untuk mengantarkan mayarakat ke pasar, sekolah ke kantor dan lain sebagainya.

Keberadaanya di kota Solok si soreonng oleh beberapa faktor diantaranya adalah faktor ekonomi yang menuntut masyarakat untuk bekerja sebagai kusir bendi untuk memenuhi kehidupan sehari-hari. Keberadaan bendi juga didoaronng oleh faktor pariwisata, bendi dijadikan sebagai transportasi wisata untuk berkeliling kota Solok sambil menikmati keindahan kota, dan faktor budaya, bendi diajadikan sebagai benda budaya atau aset budaya di kota Solok.

Namun pada tahun 2000 bendi tidak populer lagi disebabkan oleh beberapa faktor yang mempengaruhi yaitu munculnya transportasi lain yang menimbulkan persaingan antar transportasi, dan keterbatasan sumber daya untuk mengendarai transportasi tidak ada lagi, serta ketiadaan terminal bendi kota Solok.

Akan tetapi bendi masih bertahan di kota Solok sebagai transportasi budaya yang di lestarikan oleh kusir bendi, masyarakat dan pemerintah. Adapun peran pemerintah dalam melestarikan bendi adalah, melakukan pengujian terhadap transportasi bendi yang layak untuk beroperasi dikota solok, dan memberi izin mengemudi dan izin treyek untuk transportasi bendi, serta merencanakan transportasi berkelanjutan yang ramah linngkungan dan tidak menimbulkan polusi. Dengan demikian bendi masih bertahan dan masih dijaga oleh mayarakat kota solok sebagai transportasi budaya yang tidak diinginkan hilang begitu saja.

\section{SARAN}

Pertama bagi para kusir bendi diharapkan tetap menjalankan atau mengoperasikan bendi di kota Solok agar tidak punah, serta dapat mengajarkan kembali kepada generasi muda untuk mengemudi bendi. Kedua untuk mayarakat kota Solok diharapakan tetap meminati bendi atau tetap memilih bendi sebagai sarana transportasi untuk berpergian bukan hanya untuk pariwisata atau acara adat saja. Ketiga untuk pemerintah agar tetap memperhatikan transportasi bendi, dan menjaganya dalam lalu lintas dan selalu diikut sertakan dalam acara adat kenagarian di Kota Solok agar tercapai tujuan transportasi bendi sebagai sarana transportasi budaya.

\section{REFERENSI}

Adisasmita Sakti Adjie. 2012. Perencanaan Infrstruktur Transportasi Wilayah. Yogyakarta: Graha Ilmu.

Andrean Maulana, Ferry Rusgiyanto. 2018. "Penilaian Kelayakan Ekonomi Akses Transportasi Menuju Kawasan Pariwisata”. EE-Jurnal Transportasi, Vol.18, No.3.

Bagian Hukum Dan Ham Sekretariat Daerah Kota Solok. 2014. Berita Daerah Kota Solok.2014. Solok: Bagian Hukum Dan Ham Sekretariat Daerah Kota Solok.

Eko Juandri Wendi, Yurni Suasti. 2018. "Segmentasi Pasar Angkutan Bendi di Kota Solok". E-Jurnal Buana, Vol.2, No.3.

Elsa Tri Mukti, dkk. 2014. "Pengguna Model Dinamika Sistem dalam 


\section{Kebijakan Keselamatan Transportasi”. E-Jurnal Transportasi, Vol.14, No.3.}

Fikrul Hanif Sufyan, Dedi Arsa. 2017, "Kuda Bendi di kota Payakumbuh Sumatera Barat Hingga Akhir Abad Ke 20". E-Jurnal Mozaik Humaniora, Vol.7, No.1.

Gusti Asnan.2002."Transportation on the west coast of Sumatra in the nineteenth century".E-Jurnal Bijdragen tot de Taal- Land- en Volkenkunde, edisi 158.

Lisa Wahyuni. 2017, "Pelestarian Transportasi Bendi oleh Komunitas Bendi Kota Padang Sebagai Warisan Budaya". EJurnal Polibisnis, Vol.9, No.1.

Muh. Kadarisman, Dkk. 2016. "Kebijakan Manajemen Transportasi Darat dan Dampaknya Terhadap Perekonomian Masyarakat di Kota Depok" .E-Jurnal Logistik Translog, Vol.03, No.1.

Nelma Sari, dkk. 2018. "Isolasi dan Identifikasi Salmonella Sp dan Shigella Sp Pada Fases Kuda Bendi Bukittinggi Sumatera Barat". E-Jurnal Jimvet E-ISSN, Vol.2, No.3.

Nicolas Brotodewo. 2010. "Penilaian Indikator Transportasi Berkelanjutan pada Kawasan Metropolitan di Indonesia". EJurnal Perencanaan Wilayah dan Kota, Vol.21, No.3.

Paramita Mahditia. 2016. Strategi Membangun Kota . Jakarta: Caritra.
Riri Dwivivindra, dkk. 2015, "Bendi Dalam Perspektif Budaya Di Kota Padang Provinsi Sumatera Barat". E-Jurnal Humanis, Vol.Xiv, No.1.

Siswosoediro Henry S. 2009. Buku Pintar Mengurus Surat Dan Dokumen Kendraan Bermotor. Jakarta: Transmedia Pustaka.

Siti Aminah. 2018. "Transportasi Publik Dan Aksesibilitas Masyarakat Perkotaan". E-Jurnal Teknik Sipil, Vol.9, No.1.

Sugeg Wiyino. 2012. "Pengunakan System Dinamik Dalam Manajemen Transportasi Untuk Mengatasi Kemacetan Di Daerah Perkotaan". E-Jurnal Transportasi, Vol.12, No.1.

Tjahaja Limbak. 1955. Minangkabau Tanah Adat. Jakarta Bandung Amsterdam: Ganaco NV. 